\title{
The Veiled faces of prophets in the Islamic miniatures - application on illustrated manuscripts of XVI century in Konya Mawlānā Museum.
}

\section{Dr. Ibrahim Mohamed Ibrahim Elassal ${ }^{\bullet}$}

\section{Abstract:}

The study aims to recognize interpretations of veiling the facial features of divine characters like prophets in Islamic Miniatures, various designs are appeared of such veils and an obvious development had been occurred from one school of art to another. Miniaturists in religious representations were keen to give the divines remarkable features like divine halos or usage of veils.

Several researches mentioned veils' existence to cover faces of divine imagery, including prophets, but none of them made suitable analysis for such veils, with no classifying its forms, nor giving interpretations of its usage.

Islamic illustrating production is rich enough with prophets' miniatures and paintings, what made this study is necessary to be centralized on the illustrated manuscripts in Konya museum of Turkey which is belong to xvi century as an advanced stage in prophets' representations in Islamic art.

Research is introducing an analysis such veils and covers with application on miniatures found in the mystic museum related to prophet's stories with the appearance of veils to cover their facial features, with giving a short noted historical background about the prophet narration of each episode mentioned in miniatures.

\footnotetext{
- Sinai Higher Institute for Tourism and Hotels (SIT) - Egypt \& University of Cordoba - Spain ibrahimelassal2@ gmail.com
} 
"Key Words": Islamic miniatures - Illustrated Manuscripts Konya Mawlana Museum - Islamic Painting - Art History Prophets - Aniconism.

\section{Introduction:}

It's well known that the early production of Islamic miniatures had been affected clearly by calls of prohibiting and preventing miniaturists from figural imagery due to the concept of similarity with idols which leads to paganism as Muslims believed in the early centuries of Islamic calendar.

That leads the artiste to be keen no intent to create an icon of what could be interpreted as a type of Aniconism in the Islamic Art ${ }^{1}$.

Such Calls and invitations relayed on various interpretations of divine texts in the Qur'an and hadiths which are considered the main resources of Islamic belief ${ }^{2}$.

The expression of Aniconism occurred in writings of the Christian art history during quarrels in 8th century as a Byzantine Iconoclasm $^{3}$, where Byzantine Empire stood once, has been a fertile

I feel thankful and appreciated to the efforts of Mr.Mustafa Cipan head of manuscripts' section in the Museum who introduced a widely cooperation and had facilitated having the miniatures from the original copies. Special thanks to Ms. Rehab Othman who helped a lot in translating Turkish documents and texts.

${ }^{1}$ Oleg Grabar was the first scholar who used the word "aniconic" to refer to the widespread attitude in the history of Muslim cultures toward all kinds of figural representation.

Grabar O., The Formation of Islamic Art, p.6.

${ }^{2}$ Thomas Arnold gathered material on the early Islamic use of images from historical and literary sources which show that a creeping iconoclasm replaced in pious doctrine this sensible if casual practice. For example, Arnold found hadiths of Muhammad, clearly supporting the secular use of images, for example the report that Muhammad objected to figural curtains in his house-cum-mosque in Madînah but was satisfied when the curtains were cut up for cushion covers: their different orientation as cushions made them unlikely objects of prayer, and hence apparently acceptable. Whether these stories are accurate or not, they represent a straightforward and uncomplicated response to the issue. The traditional Muslim theological objection to images, which may have been observed more in the breach than in ordinary life, was eventually codified in a quite rigid form and extended to the depiction of all animate beings. Arnold T.W., Painting in Islam, p. 5-7.

${ }^{3}$ There is a clear contrast with official Byzantine Iconoclasm on this point: in Byzantium it was pictures of the saints, of Christ, and of God that were forbidden because they might be 
ground for religious debates over the nature of images and paintings ${ }^{4}$.

The thoughts of the artists had developed to allow figural representations not including the divine characters as stories of prophets and prophet Mohamed's history before introducing them with what could be considered as new features of Aniconism replaced banning their images, those features like covering the facial features of the divine persons and a flaming golden halo ${ }^{5}$.

Actually there are several studies and researches introduced analysis and explanation for such halos appeared surrounding divine faces in the Islamic painting, in general, without referring to be as a feature of Aniconism in the Islamic art ${ }^{6}$. Moreover, there's no independent researches gave an interpretation for covering the facial features of the prophets in the Islamic miniatures with the veil on their faces, which will be the main topic of this article through application on miniatures of prophets which basically enjoyed with the above mentioned features of Aniconism.

Muslim artists presented two main features to be signs of divinity in illuminating images of prophets; surrounding light halo around the

worshipped; these images could be replaced with scenes of the circus or hippodrome, which certainly do not lack animate subjects. Grabar O., The Formation of Islamic Art, p.6-8.

"iconoclasm" is the name of the era when Christian icons were destroyed in and around Byzantine Constantinople (Istanbul) in the 8th century, focuses historically on the negative influences of the representations of the divine, "aniconism" widens the range of such focus and suggests not producing figural imagery of any kind in the first place. For secular examples of the use of images on objects and in architecture see Grabar.O, Ceremonial and Art at the Umayyad Court, p. 174.

${ }^{4}$ It was claimed that it is a hopeless task to try to make a coherent sense of everything, or even most things, which have been said by Muslims about painting, not to mention the things nonMuslims have said. Nevertheless, people are trying”. Cagaman F. and others, The Topkapi Saray Museum, p.24.

${ }^{5}$ This light is interpreted by Erzeni and other Turkish mystics as representing the love of virtue and justice, inspired first in Adam, accepted by him as a trust, and inherited by generations of just men and pure women among his descendants.

${ }^{6}$ Lillys and others, Oriental Miniatures, P.84 
face and covering its features by a veil which is the main interest of this article.

Four styles of represented faces of prophets found on the XVI century; the first one is faces occurred without both features; the halo and veil, second is related to faces with both features with nonoccurring any of its details, third one is using surrounding light halo only with normal appearance of face imagination, and the fourth is faces covered by veils with no representations of any halos around ${ }^{7}$.

Stories of prophets were represented on large scale in the medieval centuries when miniaturists felt liberality in following the forbidding calls of divine characters affected by the widely Shiit influence on the artistic activity in Islamic civilization ${ }^{8}$. Twenty of prophets, mentioned in Quraan, are already represented in Islamic miniatures. Majority of their depictions are represented in manuscripts related to XVI century.

It's noted that the golden age of religious paintings was the xvi century when prophets' miniatures reached to the high point of representations by the Turkish and Persian miniaturists.

Paintings of prophets usually contain various episodes, mentioned in between the miniatures of one manuscripts, moreover the centralized manuscripts topic on prophets stories only like the manuscript of Siyer-i Nebi that narrates the life episodes of prophet Mohamed. In case of manuscripts of Konya museum, stories of prophets mentioned partially in the main subject, so that its miniatures came with other topics of the same manuscript.

From the artistic point of view, many of studies and researched put analysis for religious images like Milsten(R), Ruhrdanz (K) and

\footnotetext{
${ }^{7}$ For second style of both features see: Arnold S.T., Painting in Islam, P.96.

${ }^{8}$ The difficulties in the way of studying Islamic art have been mentioned frequently in related literature; Thomas Arnold wrote the first comprehensive text regarding the place of painting in the culture of Islam, even devoted whole chapters to such discussions.

Arnold S.T., Painting in Islam, p. 41-51
} 
Schimtez (B) who introduced a notable theory about the illustrations of prophets in the book of "illustrated manuscripts of Qisas Al-Anbiya" which was published in 19999; Their theory depends on classifying the miniatures of prophets into 3 main styles; the first one refers to representing prophets in small figures, often embedded in an elaborate setting, while the second one which is rather loosely connected to Persian miniature painting especially on shiraz and Qazwin styles occurred in using the child like faces without covering or any features of Aniconism. In addition to the $3^{\text {rd }}$ style which is considered the better known one between the artists, enjoyed with natural sizes for figures with some cases of covering faces and religious features like the golden flaming halo around the face as a kind of divinity and respect ${ }^{10}$. The studied miniatures of this research belong to the $3^{\text {rd }}$ style according to the previous classification, although the illustrated manuscripts in Konya museum were not focused in any of recent studies in the field of Islamic art history.

\section{About Konya museum}

Choosing Konya Mawlānā museum to apply the concept of the research on, is due to variety of stories of prophets in the illustrated manuscripts that preserved in. in addition to, belonging to more than one school of art like Persian miniatures and other Turkish ones. Moreover, all prophets' miniatures are belonging to xvi century which lead to centralize the research into one century facility analysis and well explain of the main idea.

Konya Mawlānā museum is located in the heart of Konya city ${ }^{11}$. It's related strongly to Jelaleddin Rumî, one of the greatest symbols of

\footnotetext{
${ }^{9}$ Milsten R. and others, Stories of the Prophets, Illustrated Manuscripts of Qisas Al-Anbiya (Islamic Art and Architecture),1999.

${ }^{10}$ Milsten R. and others, Stories of the Prophets, p.43-50.

${ }^{11}$ Konya is located $261 \mathrm{~km}$ South of Ankara, the Turkish city is known of Whirling Dervishes, and has been for 800 years. It is the seventh most populated city in Turkey. It was the capital of the Seljuk Turkish Sultanate from 1071 to 1275 . The Seljuks built numerous caravansarays along the Silk Road between Cappadocia and Konya. The city of Konya has been known by
} 
Sufism in the Islamic world ${ }^{12}$, where his whirling dervishes' order "Mevlevi" is practiced and where his mausoleum is existed.

According to the main catalogue of its illustrated manuscripts, it contains Arabic, Persian and Turkish manuscripts that are illustrated with miniatures belong to different topics and subjects of the Islamic history, between them were the stories of the prophets Ibrahim, Ismail, Jacob, Yusuf, Musa and Zakria. All at Konya's is illuminated in the Persian and Turkish manuscripts only, while the Arabic ones had no any representations of prophets according to the highly influence of prohibition calls of figural imagery.

Illustrated manuscripts found in the museum are classified to "Takaya School of art" which depended on the mystic halls of Konya and Baghdad at Turkish era, topics of paintings related to this school were influenced by Sufi thoughts and believes.

\section{First: Persian miniatures}

- Miniature painting of Prophet Musa with the devil (Plate 1)

Prophet: Musa

Manuscript's name: Sabhat al-abrār ${ }^{13}$

different names through the ages; Kuwanna to the Hittites, to the Phrygians it was Kowania, to the Romans Iconium and to the Turks, Konya. For further details about the city look ; https://sacredsites.com/middle_east/turkey/shrine_of_rumi_konya.html

${ }^{12}$ Mevlâna Jelaleddin Rumî is considered one of Islamic greatest poets and mystic philosophers, he was born near Balkh near Afghanistan in 1207 and died at 1273 . He was called Mevlâna which it means Our Guide in Persian, and he was Rumî due to the Seljuks' western, formerly Roman lands. He presented to the Islamic mystics an order called the Mevlevi ("Followers of Mevlana," or Whirling Dervishes) based on Rumî's principles and practices. For more details see; Franklin D. Lewis, Rumi- Past and Present, East and West, 2000, p. 34-52.

13 'Sabhat al-abrār' an Arabic expression means ' Rosary of the Pious', and it's considered one of the main seven books of Mesnavi that was written by Jami and was called Haft Awrang which is a Persian expression means "Seven Thrones" and related to the classic Persian literature. The seven books are: Selselat adh-dhahab"Chain of Gold"; Joseph and Zulaikha; Salaman and Absal which is a Greek story tells about a prince and his nursemaid; "Tohfat ol-ahrār" Gift of the Free"; Layla and Majnun; Kheradnāma-i Eskandari "Alexander's Book of Wisdom". 


\section{Author: Nur Aldīn AbdelRahmān Jāmīîn}

Dating: $1537-8$

Place of production: Tebriz ${ }^{15}$

School of art: Timurid ${ }^{16}$

Folio: 28 Recto

Preservation no.: 123

Sizes: $102 \times 67 \mathrm{~mm}$

Description:

Prophet Musa appears in the scène with the devil in a dialogue narrated by text appears in the upper and lower parts; Musa met him in his way of searching for the fire when he was saw an illumination and wanted to take some fire from it to his family in their return back journey from Shu'ayb (Jethro)'s land ${ }^{17}$ where Musa spent 10 years of tending his herds. According to the text, Musa

\footnotetext{
${ }^{14} \mathrm{He}$ is one of the most famous Iranian poets in mystical Sufi literature, he wrote approximately 87 books and letters, his secret of fame is due to his famous and beautiful divan Haft Awrang (Seven Thrones) which is influenced by the works of Nizami. Most of his own literature included illustrations, Jami worked within the Tīmūrid court of Herat helping to serve as an interpreter and communicator. For further details See: Schimel A., Mystical Dimensions of Islam, p.78-122.

15 one of the historical capitals of Iran, and it was considered the main artist center during the Timurid dynasty.In 1501, Shah Ismail I entered Tabriz and proclaimed it the capital of his Safavid state. For further details see: Wood (John E.)\& Tucker(Ernest),History and Historiography of Post-Mongol Central Asia and the Middle East,2006, After p.530.

${ }^{16}$ One of the Persian schools in the Islamic art, its name dates back to the Timurid Empire which was founded by Timurlane who established the empire between 1370 and his death in 1405. Many scholars considered that The golden age of Persian painting began during the reign of the Timurids, Timurid artists refined the Persian art of the book, which combines paper, calligraphy, illumination and illustration.

${ }^{17}$ It is known as Midian, and it is a geographical place and the Midianites a people mentioned in Qur'an, it's located in the "northwest Arabian Peninsula, on the east shore of the Gulf of Aqaba on the Red Sea.
} 
asked the devil about the reason of refusing to bow down to Adam $^{18}$.

Musa is represented while standing on the left side with a varied colored garment covered with different decorations all over its length. He appears while holding his famous rod in his left hand side $^{19}$, referring to the Satan with his other right hand. Musa's religious identity is accentuated by covering his face with the veil, in addition to the gilded divine light surrounding his head in a shape of a flaming halo, while Satan is represented, as usual in the illustrated depictions, in his black-skinned ugly form wearing a blue skirt with upper naked black chest.

It seems clearly that Musa's face is veiled in later time of miniature's production as a type of damaging the facial features by extending some parts of head cover, it means that the miniaturist had put an imagination to Musa's features and damaged it after feeling guilty reflecting the affection of prohibition calls of illustrating divine characters that prophet Musa is one of them in the Islamic belief, which could be assumed as an interpretation of Aniconism in the Islamic art.

The details of depiction refer to Timurid School of art due to the simple figural representations, various permanent colors, ground decorations and representations of hills regarding to Tor Mountain where Musa found the fire in the burning Bush.

Veiling style of the Musa's face is a permanent form affected by the way of painting veils spread in $15^{\text {th }}$ century following traditions of Timurid school of art like a miniature related to the seduction of

\footnotetext{
${ }^{18}$ The Quran Texts mentioned that Satan claimed that he was created from the noble fire, while Adam was a mere product of inferior clay.(Quraan 2:23-28; 7:10-17; 20:115; 27:49). Tabari devotes a long discussion to the identity of Iblis and to the reaction of the whole crowd of angeles to the certain Adam. Al Tabari A., Ta'rīkh al-rusul wa-l-mulūk, Volume 1, p.58-65.

${ }^{19}$ Musa's rod mention enjoyed with a plenty of divine texts which narrated the miraculous stick role at the palace of the Pharaoh and where it was converted into a large snake swallowing several small ones of the magicians (Qura'an 20:69). His rod also appeared with him in Sinai mountains (Qura'an 20:17-23). Al Tabari A., Ta'rīkh al-rusul, Volume 1, p 156-157.
} 
Yusuf by Zulaikha, a folio from copy manuscript of Bustan Saadi that signed by Behzad and preserved at Egyptian National Library dating back to 1488 A.D. (plate 2) ${ }^{20}$, where prophet Yusuf is appeared with no facial features that hidden under the veil which is had no determined forming design, the concept is just to hide the face in a similar way of miniature of Musa at Konya Museum by forming it partially from the cover head.

\section{- Miniature Painting of Prophet Ibrahim with Rahip(Plate 3)}

Prophet: Ibrahim

Manuscript's name: Sabhat al-abrār

Author: Nur Aldīn AbdelRahmān Jāmī

Dating: $1537-8$

Place of production: Tebriz

School of art: Timurid

Folio: 49 Verso

Preservation no.: 123

Sizes: $130 \times 95 \mathrm{~mm}$

Description:

Prophet Ibrahim appears in the depiction while setting in the frontal view on the left side, referring to his talking with the priest who set in the 3/4 quarters position, food table is centered between them. According to texts, Allah blamed Ibrahim for promising the priest for enjoying eating in case of positive respond to his call to believe in; the story is not mentioned at any of the Qur'an texts and it's narrated in some historical heritages.

Ibrahim is depicted wears a blue long garment decorated with gilded features, refer with his hand to the table where locates the

\footnotetext{
${ }^{20}$ Under number of preservation 22, Persian literature.
} 
mistake of promising the priest. Features of priesthood appeared by covering his head, moreover the beard on the face and the delegated face.

The veiled face is appeared clearly in Ibrahim's case, while the priest facial features shown despite his converting to full belief, as the text mentions, and is due to the elite positions of prophets in Muslim thoughts, that made artists keen to veil usage, moreover surrounding their faces with divine light halos.

The representation of the veil in this illustrated depiction is quite different of the previous one of prophet Musa; it seems that it's prepared to be added on Ibrahim's face proves by its independent logic forming with head cover.

Other issues are shown in the illumination like the mountain background of whole scene with 2 of people in an argument case around the story of Ibrahim and priesthood, moreover the representation of the servant who stands his hand above the left priest's shoulder.

The poor details of depictions, brilliant coloring usage, the nonideal figural representations, and natural background elements referring the illustration to Tebriz School of art that developed enough in the beginning of XVI century when the manuscript is produced.

The plate is due to the same way of veiling partially from the cover head with no any separate veils, the type that appeared in the $15^{\text {th }}$ century, following artistic painting traditions referring to Timurid school of art like that miniature of ascension of the Prophet "Miraj" of Khamsa Nizami manuscript, copy of Chester Beatty library of Dublin produced in Baghdad (Plate 4) ${ }^{21}$, where Prophet Mohamed is appeared with the same way of covering facial feature by this

\footnotetext{
${ }^{21}$ Under number of preservation CBL, Per.137
} 
partially form of veiling from prophet's cover head not in a separate way as will be clear in illuminations of Turkish schools.

This type of veiling prophets' facial features is continued on large scale at XVI century like miniatures of the study, moreover other

Illuminating production of Khorasan related to same century like a miniature for the same scene of Miraj belonging to another copy of Khamsa Nezami manuscript of Egyptian National Library (Plate $5)^{22}$.

This way of veiling faces of scared representations found as well in miniatures of Safavid School of art, as a well-known influence of Timurid art at all next artistic works in different destinations. The veiling way of prophet Mohamed's facial feature in Yusuf and Zulaikha manuscript is clear evidence (Plate 6); the manuscript which is preserved as well in the Egyptian National Library ${ }^{23}$ and its miniatures relate to Safavid School of art. Veiling style depended on partially forming form the cover head not in independent way.

This type of veils dominates majority of Persian illustrating production in general including those Persian manuscripts of Konya Museum.

\section{Second: Turkish Miniatures}

- Miniature painting of Prophet Ibrahim to sacrifice his son Ismail (Plate 7)

Prophets: Ibrahim \& Ismail

Manuscript's name: Hadikat al-Suedaa ""Garden of Pleasures"24

Author: Mohamed Ben Suleiman Fuzuli ${ }^{25}$

\footnotetext{
${ }^{22}$ Under number of preservation 142-M Persian literature.

${ }^{23}$ Under number of preservation $45-\mathrm{M}$ Persian literature.

${ }^{24}$ One of the most important manuscripts which is written in Turkish languages, and its copies spread all over the national libraries in the world, normally it's illustrated with the religious miniatures, and it was written by the poet Fuzuli.
} 
Dating: 1585

Place of production: Baghdad

School of art: Turkish

Folio: 16 verso

Preservation no.: 937

Sizes: $117 \times 111 \mathrm{~mm}$

Description:

The story of the sacrifice was so important and so well known to educate Muslims one of the most important practiced rituals in their Adha feast ${ }^{26}$. What made the depiction of sacrifice is spread enough in the productions of miniatures. It's important to refer to differentiate religious argument around the sacrifice son is Ismail in the Muslim belief while in other belief he is Isaac (Ishaq). Qur'an texts narrated the story referring to Ismail as the sacrifice $\operatorname{son}^{27}$.

Father "Ibrahim" and son "Ismail" set out for the designated place ${ }^{28}$, and when they reached it, Ibrahim disclosed to Ismail asking him about his view of this hard matter, the son urged the father to obey the order of Allah rapidly and asked him to bind his arms and legs and to turn his face from him not to take pity preventing him from running order of Allah. Which is shown on the depiction; Ismail is illuminated - in a small sized kid figural representation - lying on his front while his back is facing his elderly father, and the knife

\footnotetext{
${ }^{25}$ His full name is Muhammed Süleyman, and well known as Fuzuli, he is one of the greatest Azeri-Turkish poets, he was born around in 1495 or 1498 in Kerbela in Iraq and he died in 1556. Fuzuli composed poetry with equal facility and elegance in Turkish, Persian and Arabic, Fuzuli's works influenced many poets up to the 19th century .

${ }^{26}$ It's literally means "Sacrifice Feast", is the second of two Muslim principal feasts, according to Islamic lunar calendar, Eid al-Adha falls on the 10th day of Dhu al-Hijjah and lasts for four days until the 13th day.

${ }^{27}$ Qur'an 37:99-111

${ }^{28}$ Some references refers to Mecca, while others suggest to be Bayt el Maqdis . Al-Kisa'i M., Vita prophetarum, p.150-152.
} 
appeared clearly after fallen down from the hands of Ibrahim due to sacrificing the son with the ram. The ram is appeared in the arms of the archangel Gabriel who is seen descending from the upper corner of the composition.

Ibrahim is shown side by side with his son in the foreground, wearing a long decorative garment looking up to heaven thanking Allah with his praising attitude for sacrificing his son with ram.

The veiled face accrued covering Ibrahim's facial features; the used illuminated veil is a developed one, distinguished by its full independency from the head cover and its separation from the beard. Ibrahim's head is surrounded by a flaming divine halo as an identity of his importance in the Muslim thoughts that prevented the miniaturists from allowing the appearance of his facial features.

Ismail "The sacrifice Son" is not apotheosized; he is not surrounded by the light halo nor is his face veiled; what could be interpreted by not being a prophet in this stage of happen sacrifice story. But this probability had no artistic evidence especially Ismail was depicted in other illustrations in the same stage of the same story while his face with surrounded by halo of light, more over covering his eyes like his representation in a miniature belonging to a manuscript copy of "Hadiqat Al-Su'ada" which is preserved in the London British Museum $^{29}$ (Plate 8$)^{30}$. It will be appeared in next images that belongs to the same miniaturist that he add the divine light to the head of prophet Joseph when he was a kid and before being a prophet, but with a minority of Aniconism features by not using the veil on his face(Plate 10).

The features of Turkish school of art are clearly appeared in the depicted scene like the advanced variety of un matching colors usage like colored rocks on the right hand side, blue color of the

\footnotetext{
${ }^{29}$ With number of preservation Or.12009

${ }^{30}$ Milstein (R.), Miniature Painting in Ottoman Baghdad, Istanbul, 1990,Pl.V
} 
ram, in addition to the good distribution of scene' issues, and richness of natural elements that fulfilled all areas of the illustrated image.

The miniature presents a second type of veils used on prophet's faces, it's related to manuscripts of Turkish traditions at Konya museum this type which is formed separately from the cover head not partially as those of Persian manuscripts. The Turkish veil style which is appeared in the scene used on large scale of Turkish illustration of the same century of XVI, like a miniature of prophet Mohamed in his way to Medina (Plate 9) from Siyar-I nabi manuscript of Chester Beatty library of Dublin ${ }^{31}$. This type is obviously different from the proceeding type of Persian illustrations by its independent forming from the head itself.

\section{Miniature Painting of Prophet Jacob in a meeting with prophet Yusuf and his brothers. (plate 10)}

Prophets: Jacob \& Yusuf

Manuscript's name: Hadîkat üs-Süedâ ""Garden of Pleasures"

Author: Mohamed Suleiman Fużūlī

Dating: 1585

Place of production: Baghdad

School of art: Turkish

Folio: 20 Recto

Preservation no.: 937

Sizes: $114 \times 136 \mathrm{~mm}$

Description:

The highly mention of Joseph's story in Qur'an assumed un usual importance to its episodes in the production of Islamic miniatures in

\footnotetext{
${ }^{31}$ Under number of preservation CBL T419.
} 
general; many of manuscripts all over the xiv, xv, xvi and xvii centuries gave a special interest to the most beautiful story as it said literally in chapter 12 of Qur'an that has given the name of the prophet "Surat Yusus".

The story tells how the brothers, jealous of their father's love from Yusuf, tried to get rid of the boy expressing their anger and hate towards him. The scene shows a conversation between them and the elderly father Jacob trying to persuading him to allow the young boy to accompany them in fun trip they organized to achieve their main goal in disappearance of their brother.

Jacob appears setting in the $3 / 4$ setting profile with the halo flaming light around the head and the veil covers his facial features, referring with his hands to sons who are standing in arrange on the left depiction hand side, while Yusuf is standing the nearer one to Jacob with the divine halo around his head, and no veiled face appeared in his figural representation.

The disappearance of the veiled face in Yusuf illumination is due to not being a prophet yet in this episode of the story, which is repeated in the previous miniature of Ismail in the sacrifice scene (Plate 7). Although Josef is distinguished by using the flaming halo while Ismail not. The used veiled in Jacob's face sizes smaller than of Ibrahim, but enjoys with the same independence from the head cover design.

The veil at Jacob's imagery is transparent enough to show details of face like round eyes and frame of his face, in an indication of a new veiling way at Konya museum's manuscripts.

As it's mentioned previously that 2 main features had been used to distinguish divine images of prophets; flaming halo and veils that both were painted accompanied or separately, but this miniature indicates to the priority of veiling face than fire halo in case of characters that are considered more divine than others, although the halo commonly spread in Islamic art in general. The miniaturist 
veiled face of prophet Jacob and didn't use it to cover Prophet Yusuf's facial features, due to the more divinity of Jacob in this episode of the story than his son.

The same meaning and indication appeared in some illustrations of prophet Mohamed and Imam Ali; when the first appears with both features while the second appears with only the flaming halo around his face with no any veils. Like a miniature of Ghadir Khum ${ }^{32}$ at another copy of Hadîkat üs-Süedâ that is catalogued at Egyptian national library (Plate 11$)^{33}$, referring to the divinity of veils than halos.

- Miniature Painting of Prophet Yusuf being rescued from the pit. (plate 12)

Prophet: Yusuf

Manuscript's name: Hadîkat üs-Süedâ ""Garden of Pleasures"

Author: Mohamed Ben Suleiman Fużūīī

Dating: 1585

Place of production: Baghdad

School of art: Turkish

Folio: 22 Verso

Preservation no.: 937

Sizes: $112 \times 133 \mathrm{~mm}$

Description:

\footnotetext{
${ }^{32}$ The event of Ghadir Khumm is one of the most important occasions at Shia's belief, where prophet Mohammad announced "Al welaya" To Ali; Shia Muslims believed that it means his right in Caliphate, while Sunnis believe that refer to Ali's position with no indication to authority. The day's anniversary in the Islamic Calendar locates $18 \mathrm{Dhu}$ al-Hijjah which is celebrated by Shias as Eid al-Ghadir up till now. For further details see: Elassal I, Shi'i's influences on paintings of "Ghadir Khumm" in the Islamic manuscripts - Archeological artistic study, Tourism and Hotels Journal, Issue 22, 2015, P.5-35.

${ }^{33}$ Under number of preservation (81-turkish history Talaat)
} 
The depiction tells one of the earlier and important episodes narrates that Yusuf's brothers cast him into a dark and secluded pit till the merchants passed by on their way to Egypt; one of them lowered a bucket into the well and when it emerged, there sat Yusuf which was a surprise. Later on, the caravaneer brought Yusuf to his encampment. Yusuf's brothers, who had been waiting nearby, suddenly appeared and claimed that Yusuf was a runaway salve whom they were willing to sell.

Yusuf is depicted in the middle of a pit appeared in the middle bottom of the scene, he is shown with the flaming divine halo surrounds his head. He appears with the archangel Jibrail who in the prototype assists Yusuf in his efforts to seat himself in a merchant's bucket; the angle's role not mentioned at any of Qur'an texts around the story.

Outside the pit, the man who draws Yusuf up in the bucket is accompanied by another astonished traveler. Moreover number of people and animals surrounded the scene, while Yusuf's brothers had been waiting nearby as mentioned above.

The veiled face is depicted this time in a different way in Jibrail's representation by non- usage of the common veil but by not clearing the facial features of him through damaging it or not depicting it basically.

It's noted that another technique of depicting Yusuf in this scene had appeared in the artist school of Bukhara in the xvii century depends on non-usage of veils on his face, more over being in the pit without representations of archangel Jibril like a painting miniature of manuscript Yusuf and Zulaikha (plate 13) ${ }^{34}$, is persevered in the national library of San Petersburg ${ }^{35}$, and dates back to 1615, belonging to Bukhara school of art. Joseph is appeared in the composition with no facial features but without

\footnotetext{
${ }^{34}$ Pugachenkova g., galerkina О., Миниатюры средней Азии, Москва, 1979, PI.54

${ }^{35}$ Number of reservation: MS IOS AS Uzbek SSR 1433.
} 
using those veils; the artiste keen to unclear his face with using flaming divine halo.

- Miniature Painting of Prophet Jacob being suffers. (plate 14)

Prophets: Jacob

Manuscript's name: Hadîkat üs-Süedâ ""Garden of Pleasures"

Author: Mohamed Ben Suleiman Fużūlī

Dating: 1585

Place of production: Baghdad

School of art: Turkish

Folio: 24 Verso

Preservation no.: 937

Sizes: $114 \times 96 \mathrm{~mm}$

Description:

Jacob is depicted while suffering after his sons returned back to him without his beloved one Joseph; it's one of the most important episodes of the story which narrates the sadness of Jacob upon his son which ends with the final dramatic scene of meeting both in Egypt when Yusuf raised his parents on the throne as Qur'an mentioned $^{36}$.

Jacob is appeared with all signs of sadness like lying with his hand upon his face, and his guilty sons surround him can do nothing to their elderly father.

He is depicted with no flaming halo around the head in unusual position to prophets' representations in this manuscript and the ottoman artistic school of Baghdad that the miniature belongs to.

${ }^{36}$ Quran12: 100 
Despite the disappearance of the divine halo, the miniaturist is keen to veil his face in indication to the importance of veiling faces more than surrounding them with the divine halo.

The used veil is a developed one used by the miniaturist in the depictions of the same manuscript of Fuzuli sizes enough space to hide all facial features of the divine character of the prophet, and follow the same design of independency from the cover head as it's found in the previous miniatures.

The details of the ottoman school of Baghdad are shown clearly through the decorated foregrounds, facial features of the attendants and fulfill of the background with architectural elements and various decorations, in addition to the well distributed elements of the illumination all over the depiction scene.

Veiling style at Jacob's face indicates to the $2^{\text {nd }}$ types of veils have been introduced in this article by its separation from the cover head which is spread in Turkish illumination in general and Indian school of art as well. This type was introduced in latest of xV century and had been continued later in Turkish and Indian arts like that miniature of Prophet Solomon when the angel of death eyes a man in his court (Plate 15), a folio from the wonders of creations and the oddities of existence of Qazwini which is persevered at Princeton university library ${ }^{37}$, whose paintings date back to late seventeenth century, depicting the same separate way of veiling prophet's face.

- Miniature Painting shows the martyrdom of Prophet Zakariya. (plate 16)

Prophets: Zakariya

Manuscript's name: Hadîkat üs-Süedâ ""Garden of Pleasures"38

Author: Mohamed Ben Suleiman Fużūlī

\footnotetext{
${ }^{37}$ Under number of preservation MSS Garrett 82.

${ }^{38}$ Another copy bearing the same name of manuscript.
} 
Dating: 1604

Place of production: Baghdad

School of art: Turkish

Folio: 49 Recto

Preservation no.: 101

Sizes: $160 \times 104 \mathrm{~mm}$

Description:

The martyrdom of Prophet Zakariya "Zacharias" played an important role in both Sufi and Shi'ite interpretations. So that it occupies a gran care in the Muslim artist's mentality that is affected strongly with the mystic thoughts in the xvi century; what is appeared in the plenty of prophet's miniatures production.

The scene is generally depicted with Zakariya's enemies were closing in on him, a tree trunked opened up and Zakariya hide inside it. However, the edge of his robe was visible sometimes through a crack in the tree, while Satan revealed it to the pursuers, advising them to cut the tree in half vertically in order to kill the prophet concealed in the trunk.

The main tree of the whole event is centralized and 2 men using the cutting method taking the advice of Iblis as mentioned before. Moreover, figural representations for witnesses and enemies are depicted. The illumination belongs to Turkish School of Art in Baghdad which is clear in using brilliant colors with the ottoman style of garments and robes.in addition to, the realism way in figural representations and logic distribution of proportions in bodies' representations and elements all over the scene.

Neither the veiled face nor any of halos is appeared in the whole scene, is due to being the representation of prophet's figure is hidden in the tree, but the damage veiling way to the face of the devil is used in this painting miniature leading to the disappearance of his facial features. And this a different representation of the Satan images in Islamic illuminated manuscripts. 
The miniature refers to veiling faces in Konya manuscripts, wasn't only for prophets, but it extended to include Satan even in a different way, but it's one of prophet's miniature illustrations.

\section{Historical summary about Prophets of the miniatures:}

\section{Musa:}

Musa or Moses who was one of Muhammad's predecessors, he had a special importance as the messenger who heard Allah's voice and brought a written law ${ }^{39}$.

He was sent to the Governor of Egypt (pharaoh) with the message of true religion rather than to make him release the children of Israel. His story has many episodes are mentioned in various resources such as biblical elements with rabbinical literature and other ones. His life from birth to death came on the priority of miniaturists no less eventful than that of Yusuf; the illustrative cycle of his prophetic mission is consequently as rich and varied enough.

Between the common episodes appeared in the illustrated manuscripts were his representation as infant in the river, his existence in front of the Burning Bush ${ }^{40}$, meeting with magicians and his rod while swallowing their arts, the crossing of his followers and drowning of the Egyptians in the sea, his episode with Qarun "Korah"41 and his treasures, his episode with Khadir ${ }^{42}$ and his stories in mount of Sinai. His representation in Islamic miniatures not appeared only in the manuscripts narrating stories of

\footnotetext{
${ }^{39}$ Qur'an 7:156; 42:11

40 The texts recount that Moses was seeking for fire when he saw illumination, he wanted to take some fire from it but the light played hide and seek with him, circling round the tree and reappearing on top of it. The prophet was afraid, then he heard Allah speaking to him, he was standing in front of a large tree, small flames dart out from its leaves this it's the Burning Bush.

${ }^{41} \mathrm{He}$ is the relative of Musa who became rich and powerful and led a rebellion against him.

${ }^{42}$ A mysterious saint of ancient syncretic origins, he was identified by Muslims as the servant of God (Qur'an 18:59-81).
} 
prophets, but also in other ones like Khamsa and Haft-Awrang groups as a kind of frequency in depiction.

\section{Ibrahim:}

Abraham is the ancestor of the Arabs through his son Ismail. He enjoys a high level of importance in the Muslim's belief; he is the friend of Allah (Khalil Allah), and he is mentioned no less than twenty-five Qur'anic chapters. He gave the both to other 2 prophets; Ishaq (Isaac) who is the root Israel children and Ismail (Ishmael) who is the grandfather of all Arabs trips.

Several episodes from his life were continually retold, interpreted and illustrated. Especially his thrown in the fire, King Namrud (Nimrod) ${ }^{43}$ flying to heaven, He while sacrificing his son Ismail, and his building of the Kaaba ${ }^{44}$.

\section{Ismail:}

Son of Abraham and the origin of all Arabs, his mother was the Egyptian woman "Hager", and he is associated with the scene of sacrifice in Islam which is highly connected to their great feast and divine ritual of pilgrimage.

His figural illustrative representation in the Islamic miniatures related only to his famous scene of sacrifice with no other depictions belonging to him found in illuminated manuscripts.

\section{Jacob:}

Jacob was the elder father in Yusuf narrative story which occupied a large interest in the production of prophet's miniatures in the Islamic medieval centuries. He was son of Ishaq (Isaac) and grandson of Ibrahim. His illustrated representations were parts of Yusuf episodes as the father of 11 sons the origin of Israel children generations who stayed till Moses and crossed with him the sea.

\footnotetext{
${ }^{43}$ One of the greatest kings in the history of the world and an archetypical infidel, enemy of God. AlTabari A., Ta'rīkh al-rusul, Vol.I, P.163-170

${ }^{44}$ In Mecca as a center of pilgrimage and made it into a place of pure monotheistic belief.
} 
This due to the only mention of Jacob in the Qur'anic chapters a s a part of Yusuf story; this clearly shows the high influence of Qur'an texts on the mentality of miniaturists in illustrating episodes existed in its texts not in the historical texts or other resources content.

\section{Yusuf:}

A complete chapter in Qur'an is given to story of prophet Yusuf (Qur'an:12), in a sign of assuming an unusual importance, describing it with the most beautiful stories as Qur'an said (12:1-2). That leads to an unusual importance of episodes of his story in the illustrated Islamic manuscripts to leave a rich account of miniatures belonging to him. Especially with the spread of grand poetic literature writings related to episode of him with the Egyptian Lady "Zulaykha" like those that were written by Abdelrahman Al Jami in Herat and by Hamd Allah in Istanbul inspired artists in both Iran and the ottoman empires to decorate many manuscripts with detailed cycles.

The representations of Yusuf includes his brother while beating him in the bit, being rescued from the pit, the merchants showing respect to him, being sold in Egypt, in prison, in palace of Zulikha, situation of Egyptian ladies when slice their hands instead of fruits by his appearance, his situation of the famine... and others.

\section{Zakariya}

$\mathrm{He}$ is the father of Prophet Yahya (John the Baptist), he is mentioned in Qur'an texts for example (3:32-36 ; 4:1-15 ; 19:8990).he was sent to the children of Israel with the message, and he related to Virgin Mary by bringing her up with him in the cave when she blessed all place by her high spiritual position. Zakria was elder enough when he asked Allah to giving him a birth to son who was later on Prophet Yahya.

His martyrdom scene is considered the only found belongs to him in the Islamic Miniatures, and it was associated with Sufis and 
Shiites because Zakariya's story had a spiritual mystical episodes lead such scene to spread up in the illuminated manuscripts and in the Muslim artistic galleries.

\section{Conclusion:}

This Article presents an interpretational analysis for usage of veiled faces in prophet's representations in Islamic Miniatures with application on seven samples preserved at Konya Museum in Turkey where 6 prophets are figured with features of divinity that occurred with clarity of prohibitions calls influence in illustrating divines in Islamic paintings in general. Selected samples belong to Persian and Turkish schools of art and photographed by the permission of Turkish museum, they were abstracted from various original manuscripts according to containing representations of such veils at that cover the facial features of the prophets. The article introduced 16 miniatures to support the explanation of veiling concept and analyzing its types and purpose.

Following issues summarize the conclusion of the study:

- Veiling faces in the figural representations of prophets is one of 2 main features indicating to divinity and representing an interpretation of Aniconism in Islamic Art; the priority at miniaturists' mind is to veil the face though the usage of flaming halo is the origin remark of divinity. All miniatures of prophets at Konya Museum gathered between both features expect their representations in kids' stage like Yusuf in (plate 10) who is represented with the flaming halo only, and Ismail in (plate 7) who had no features of Aniconism.

- 2 main types of veils are introduced through illustrations of Konya Museum;

- First related to Persian manuscript of Sabhat al-abrār and marked by its partially form from the cover heads like presentations of Musa (plate1) and Ibrahim (Plate 3). It was appeared in XV century and had been continued in Timurid and Safavid schools of art in the xvi century like representations of prophet Mohamed at Miraaj 
(plates 4,5,6). This type had no independent style from the face and formed through the head itself.

- Second type is distinguished by its independent forming from the cover head of prophet, and it's related to ottoman manuscript of "Hadiqut al-Sooada" like representations of Ibrahim (plate 7) and Jacob in (plate 14). This type was remarkable features of veiled faces in the xvi century like prophet Mohamed's veil at (plate 9) and continued to be used in xvii century like Solomon's veil of (plate 15). The type has its own design in a separately way from the cover head.

- Transparent type of veils appeared in miniatures of the museum and showing details of eyes behind, and forming face style like miniature of Jacob (plate 10).

- The artists used sometimes the way of damaging facial features for some characters like archangel Jabriel (Plate 12) and Satan or Iblis (Plate 16) which is a trail of hiding their features, due to absence knowledge about their imagination. This way not used for figural depictions of prophets as an indication of using veils instead, though the alternatively unclearing facial features in the miniatures of xvii centuries.

- Miniaturists were keen in using the veiling faces more than the lighted halos as a priority of divinity and expressing Aniconism like the ottoman miniature of Jacob in his sadness after losing Yusuf (P1.14), with the difference of divinity between prophet Mohamed and Imam Ali in (Plate 11) which is reflecting the idea of veils priority at prophet Mohamed's face only, while Ali's face only is surrounded by the well-known flaming halo.

- Introducing an interpretation for the artistic expression "Aniconism" and associating it with Islamic art historical studies, relying on investigations of Oleg Grabar, Feliz Cagaman and others. This interpretation indicates to principal features, veiling faces is one of them. Islamic miniaturists were affected by callas of prohibitions through veiling faces and flaming halo's usage instead of preventing from illuminating divine characters. 


\section{Bibliography}

1. Adamova( A.), Mediaevel Persian Painting : the evolution of an artstic vision, New York, 2008.

2. Alaine (W.), Islam, Faith. Art. Culture, Manuscripts of the Cheaster beaty Library, Dublin, 2009

3. Al-Ṭabarī (A.M.), Ta'rīkh al-rusul wa-l-mulūk, Annals of the Prophets and Kings,Edited by: M.J. de Goeje, 1879-1901.

4. Arberry( A. J.), Classical Persian Literature, New York, 1958.

5. - --:---.., The Mystical Poems of Rumi, university of Chicago Press, 1974.

6. Arnold (T. W.), Painting in Islam: A Study of the Place of Pictorial Art in Muslim Culture, New York, 1965.

7. Barry (M.), Figurative Art in Medieval Islam and the riddle of Bihzad of heart, Washington, 2004.

8. Bagci (S.), Konya Mevlana Muzesi, Resimli Elyazmalari, Istanbul, 2003

9. Binyon(L.), Wilkinson( J. V. S.), and Gray(B.), Persian Miniature Painting (including a critical and descriptive catalogue of the miniatures exhibited at Burlington House, January-March, 1931), New York, 1933.

10.Blochet(E.), Catalogue des Manuscrits Persans dans la Bibliothèque Nationale, t. 3, Paris, 1928.

11.Cagaman (F.), and Tanindi (R.), The Topkapi Saray Museum: The Albums and Illustrated Manuscripts, 1986

12.Canby (S.), Persian Painting, New York, 1993.

13.------ Persian Masters: Five Centuries of Painting, Bombay, 1990.

14.Ettinghausen (R.), La Peinture Arabe, Geneve, 1977

15.--- Islamic Painting, The Metropolitan Museum of Art Bulletin (Fall 1978), New York, 1978.

16.------, A Journey to Persia: Jean Chardin's Portrait of a SeventeenthCentury Empire, London, 1996.

17.Filiz Cagman, Islamic Miniature Painting, Topkapi saray Museum, Istanbul. 1979.

18.Franklin D. Lewis, Rumi- Past and Present, East and West, 2000

19.Grabar (O.), "Ceremonial and Art at the Umayyad Court, Ph. D. thesis, Princeton University, 1955

20.-----, and Blair(S.), Epic Images and Contemporary History: The Illustrations of the Great Mongol Shahnama, Chicago, 1980

21.-------, The Formation of Islamic Art, Revised and Enlarged Edition, 1987.

22.------------, Mostly Miniatures, An Introduction to Persian Paintings, Oxford, 2000

23.------------, Master Pieces of Islamic Art, the decorated page from the 8th to 17th century, New York, 2009.

24.Gray(B.), Persian Painting from Miniatures of the XII-XVI Centuries (Twelve ColorPlates), Bern,1947.

25.Guest(G.D.), Shiraz Painting in the Sixteenth Century (with 50 Plates), Washington, 1948. 
26.Hattstien (M.), Islamic Art and Architecture, American University in Cairo, 2001. 27.IsIten (M.), Early Ottoman art, the Legacy of the Empires, Istanbul, 2002

28.Labib(S.), The Era of Suleyman the Magnificent, Crisis of Orientation, International journal of Middle East studies, London, Cambridge University Press, 1979

29.Lillys (W.), Reiff (R.), Esin (E.), Oriental Miniatures : Persian, Indian, Turkish, 1965

30.Milstein (R.), Islamic Painting in the Israel Museum, 1984.

31.---------, Miniature Painting in Ottoman Baghdad, Istanbul, 1990

32.---------, Miniature Painting in Ottoman Baghdad, Istanbul, 1990

33.---------, and others, Stories of the Prophets, Illustrated Manuscripts of Qisas Al-Anbiya (Islamic Art and Architecture), 1999.

34.Pugachenkova g., galerkina О., Миниатюры средней Азии, Москва, 1979.

35.Robinson( B. W.), The Topkapi saray Museum, The Albums and Illustrated Manuscripts, Istanbul, 2001.

36.Schimmel(A.),Mystical Dimensions Of Islam, The University of North Carolina Press, 1975.

37.Stchoukine (I.), La Peinture Turque d'Après les Manuscrits Illustrés de Sulayman Ier à 'Osman II (1520-1622), Paris, 1966.

38.Titley (N. M.), Persian Miniature Painting, and its Influence on the art of Turks \& India, The British Library, 1983.

39.Welch (S. C.), Persian Painting, New York, 1976

40.Wood (J. E.)\& Tucker(E.),History and Historiography of Post-Mongol Central Asia and the Middle East,2006 


\section{Plate 1:}

Miniature painting of Prophet Musa with the devil

Sabhat al-abrār, Konya Mawlānā Museum,123 , 28 Recto, 15378AD, Tebriz, Timurid, $10.2 \times 6.7$ $\mathrm{cm}$.

S: Bagci Serpil, Konya Mevlana Muzesi, Resimli Elyazmalari, Istanbul, 2003, Pl.p.61

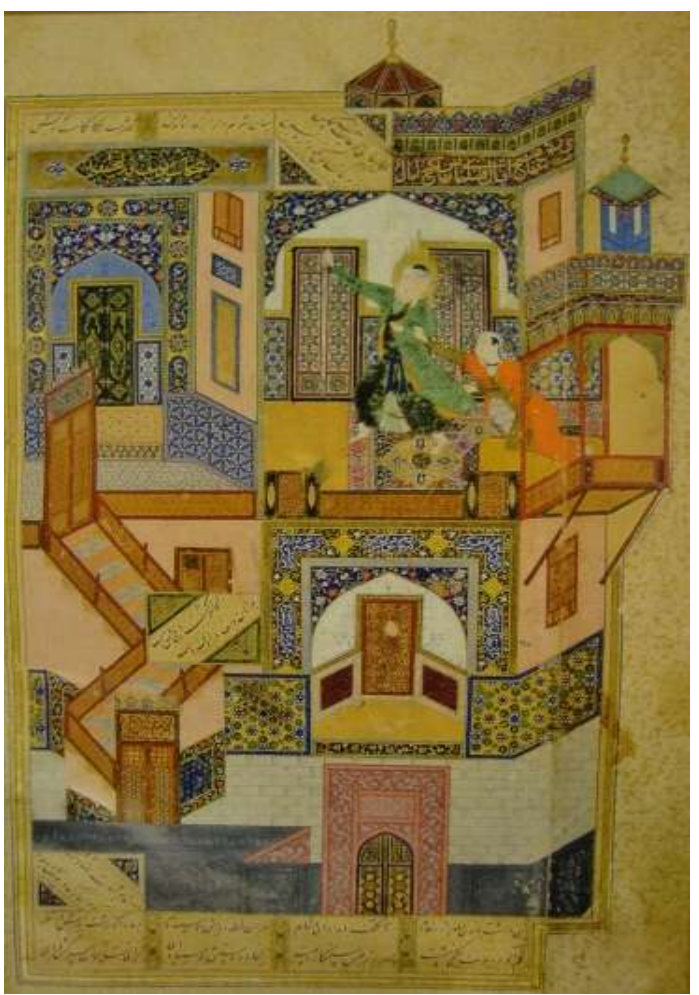

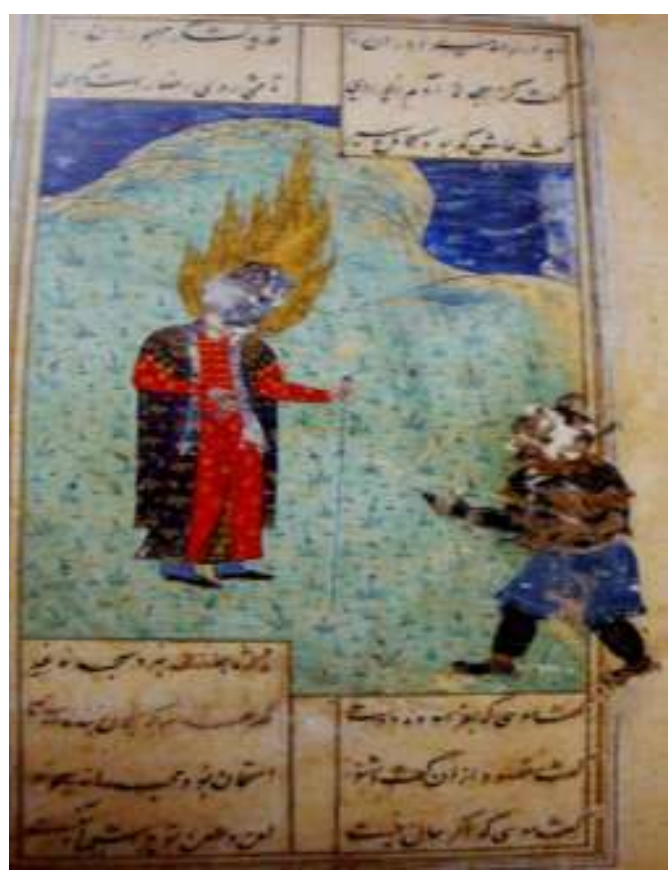

Plate 2:

The seduction of Yusuf, Bustan Saadi, Egyptian national library, 22-persian Literature, 1488 A.D., Behzad, Timurid School of art, $17 \times 21 \mathrm{~cm}$.

S: Original manuscript at Egyptian national library 
Plate 3:

Miniature Painting of Prophet Ibrahim with Rahip

Sabhat al-abrār, Konya Mawlānā Museum,123, 49 Verso, 15378AD, Tebriz, Timurid, $130 \times 95 \mathrm{~mm}$.

S: Bagci Serpil, Konya Mevlana Muzesi, Resimli Elyazmalari, Istanbul, 2003, Pl.p.62
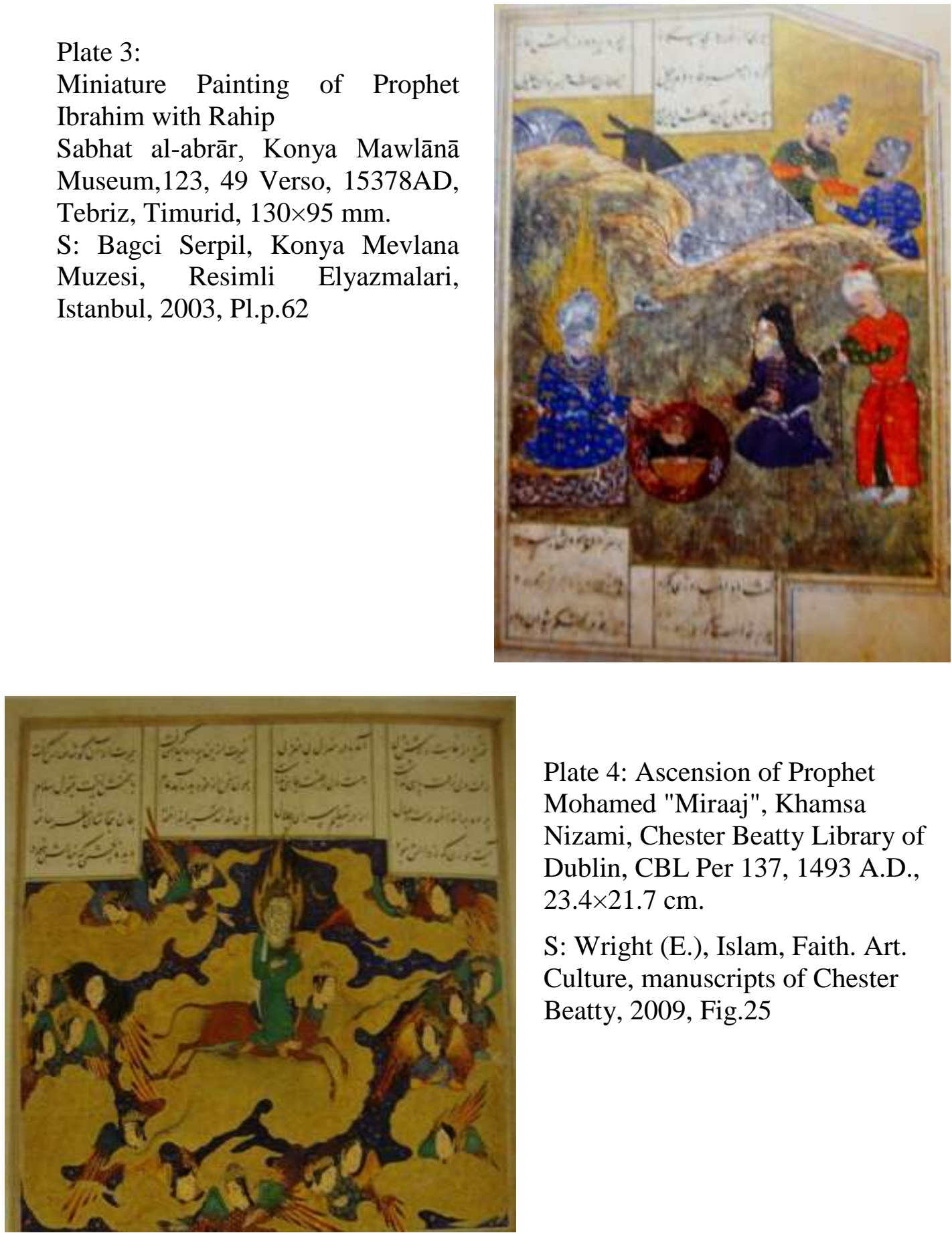

Plate 4: Ascension of Prophet

Mohamed "Miraaj", Khamsa Nizami, Chester Beatty Library of Dublin, CBL Per 137, 1493 A.D., $23.4 \times 21.7 \mathrm{~cm}$.

S: Wright (E.), Islam, Faith. Art. Culture, manuscripts of Chester Beatty, 2009, Fig. 25 
Plate 5: Ascension of Prophet Mohamed "Miraaj", Khamsa Nizami, Egyptian National Library, 142 - Persian Literature M, 1579 A.D., Khursan, $17 \times 28 \mathrm{~cm}$.

S: Original manuscript at Egyptian national library
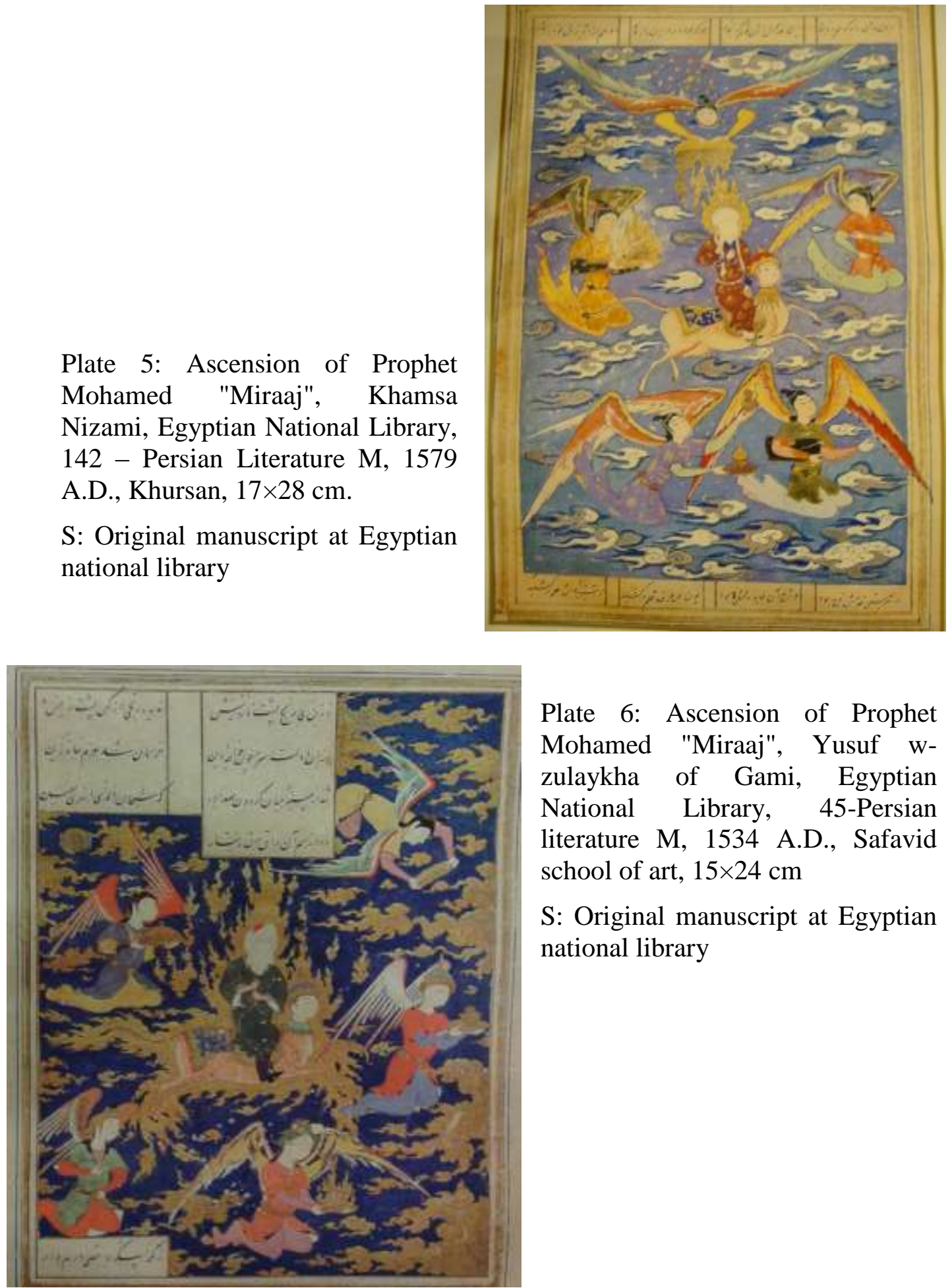

Plate 6: Ascension of Prophet Mohamed "Miraaj", Yusuf wzulaykha of Gami, Egyptian National Library, 45-Persian literature M, 1534 A.D., Safavid school of art, $15 \times 24 \mathrm{~cm}$

S: Original manuscript at Egyptian national library 
Plate 7: Miniature painting of Prophet Ibrahim to sacrifice his son Ismail, Hadikat al-Suedaa, Konya Mawlānā Museum, 937,1585AD, Baghdad, Turkish, 16 Verso, $117 \times 111 \mathrm{~mm}$.

S: Bagci Serpil, Konya Mevlana Muzesi, Resimli Elyazmalari, Istanbul, 2003, Pl.p.116.
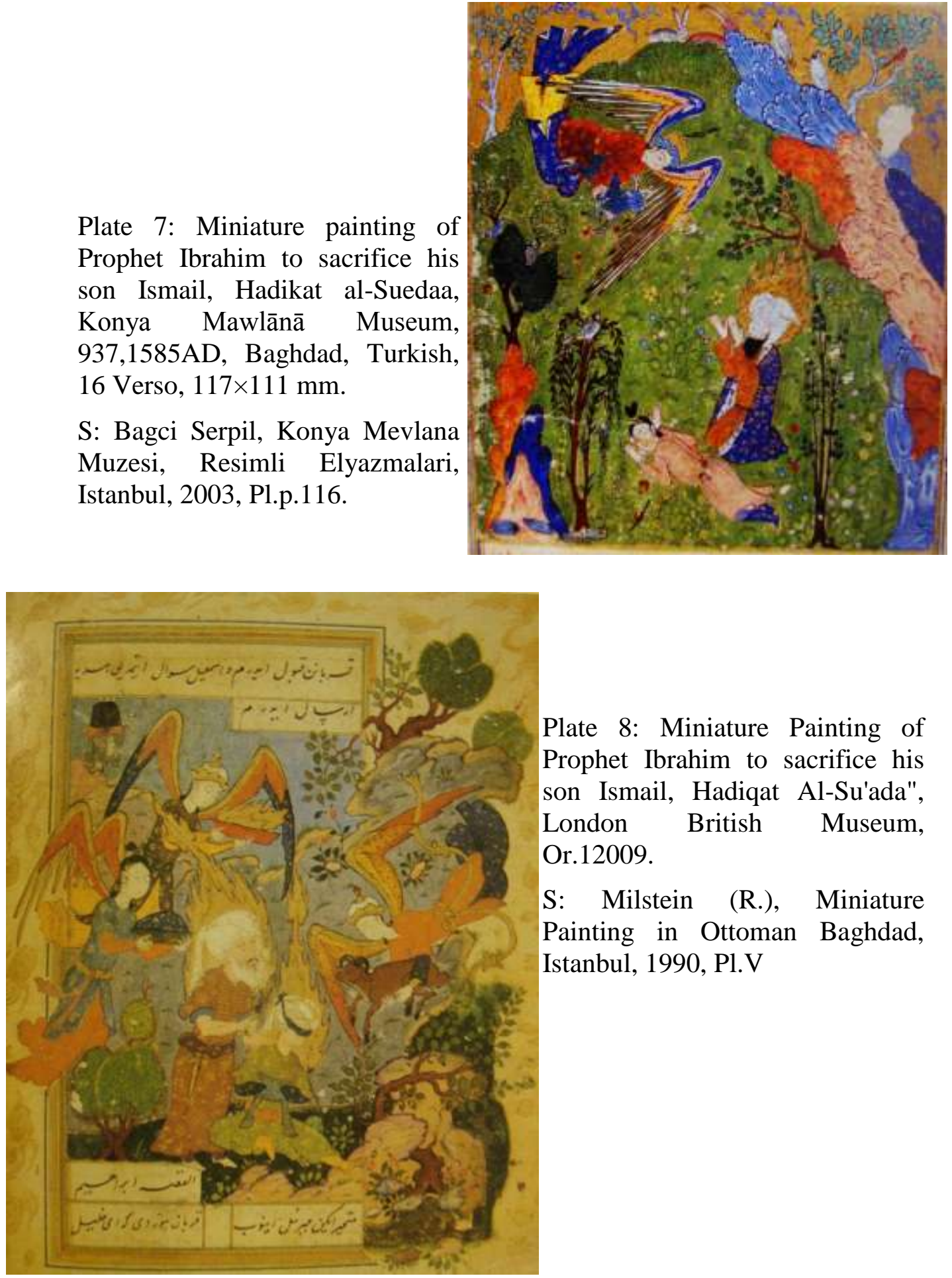

Plate 8: Miniature Painting of Prophet Ibrahim to sacrifice his son Ismail, Hadiqat Al-Su'ada", London British Museum, Or.12009.

S: Milstein (R.), Miniature Painting in Ottoman Baghdad, Istanbul, 1990, Pl.V 
Plate 9: Prophet Mohamed in His way to Al Medina,Siyar-i-nabi, Chester Beatty library of Dublin, CBL T419, 1594-95 A.D., Turkish School of Art, $37.4 \times 27 \mathrm{~cm}$.

S: Wright (E.), Islam, Faith. Art. Culture, manuscripts of Chester Beatty, 2009, Fig.6
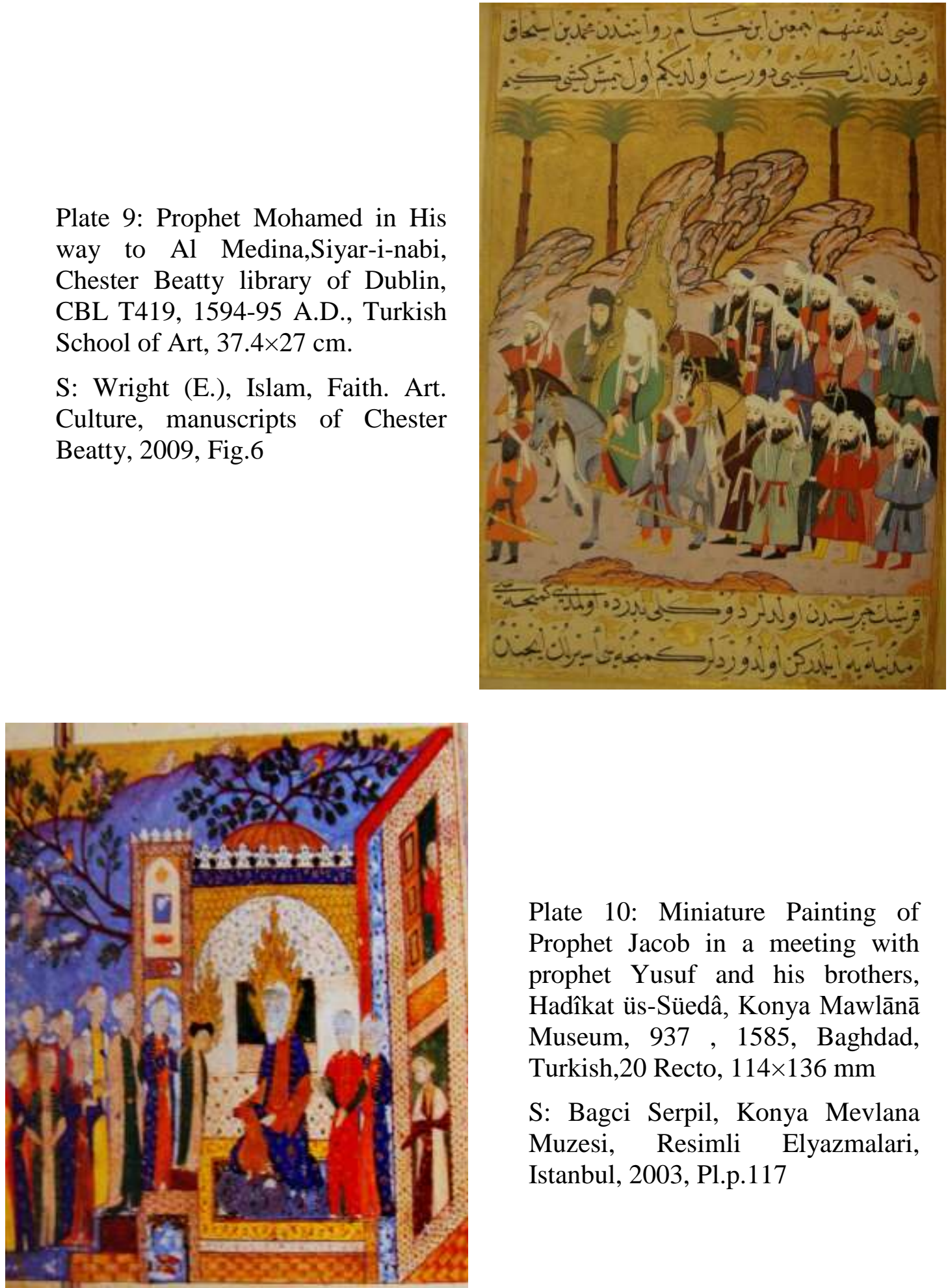

Plate 10: Miniature Painting of Prophet Jacob in a meeting with prophet Yusuf and his brothers, Hadîkat üs-Süedâ, Konya Mawlānā Museum, 937 , 1585, Baghdad, Turkish,20 Recto, $114 \times 136 \mathrm{~mm}$

S: Bagci Serpil, Konya Mevlana Muzesi, Resimli Elyazmalari, Istanbul, 2003, Pl.p.117 


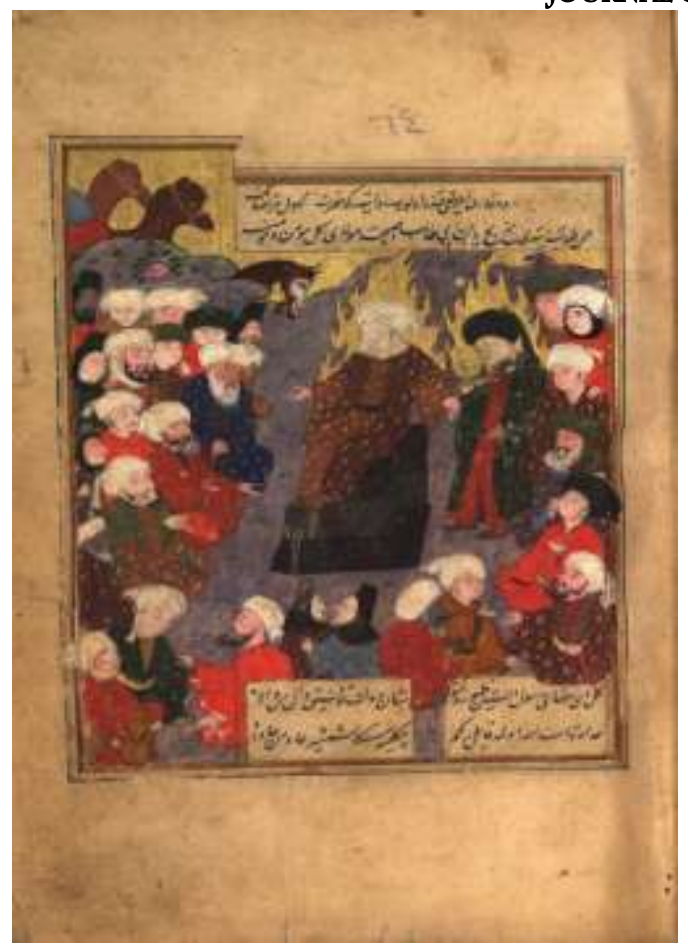

Plate 11: Prophet Mohamed and Imam Ali at Ghader Khum, Hadîkat üs-Süedâ, Egyptian National Library, 81- Turkish History Talaat, 1551 A.D.

S: Original manuscript at Egyptian national library

Plate 12: Miniature Painting of Prophet Yusuf being rescued from the pit, Hadîkat üs-Süedâ, Konya Mawlānā Museum, 937, 1585, Baghdad, Turkish,22 Verso, $112 \times 133 \mathrm{~mm}$.

S: Bagci Serpil, Konya Mevlana Muzesi, Resimli Elyazmalari, Istanbul, 2003, Pl.p.118

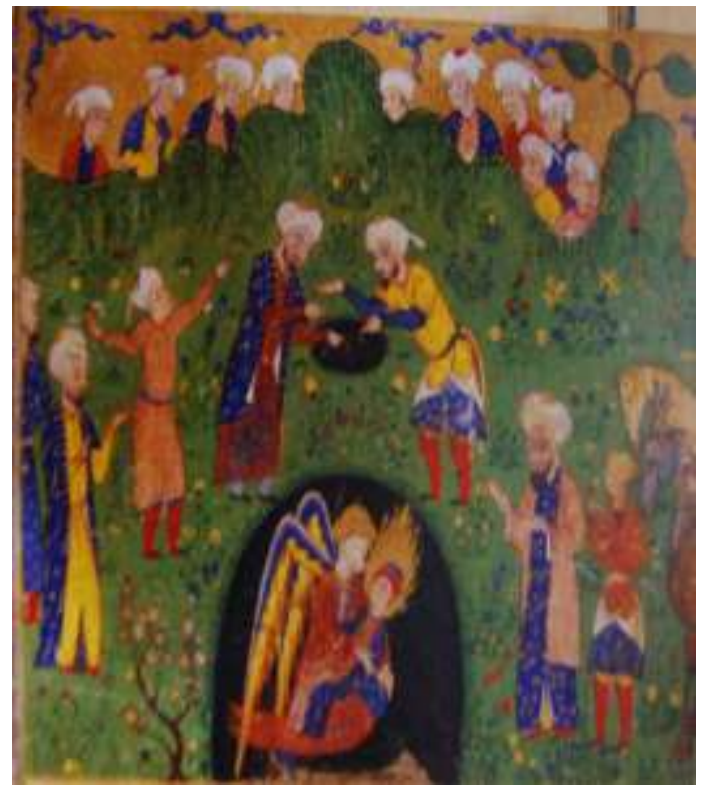


Plate 13: Miniature painting of Prophet Josef thrown into the well by his brothers, manuscript Yusuf and Zulaikha, Bukhara, 1615 AD National library of San Petersburg MS IOS AS Uzbek SSR 1433., $22.8 \times 12 \mathrm{~cm}$.

S: Pugachenkova g., galerkina O., Миниатюры средней Азии, Москва, 1979, P1.54
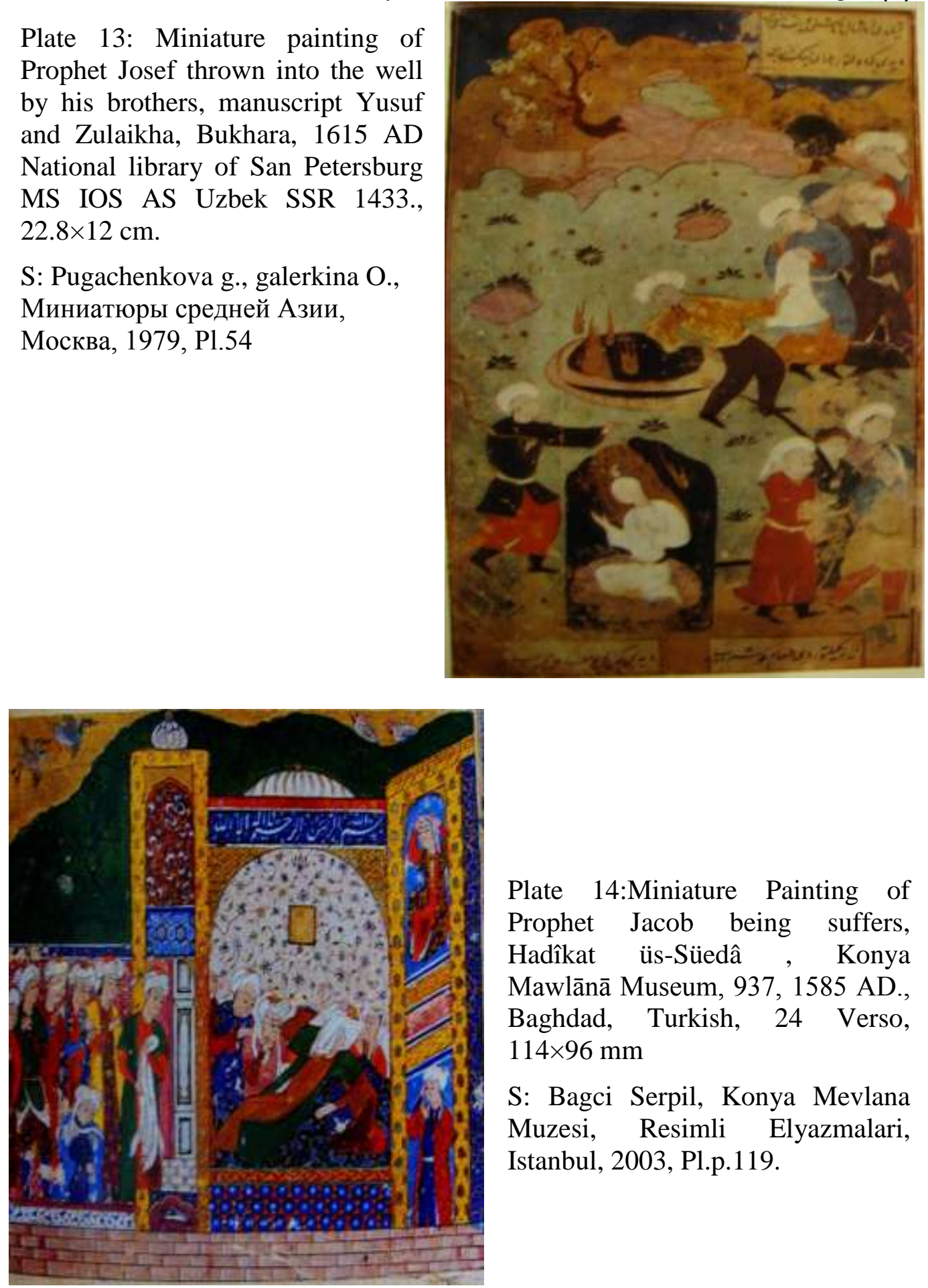

Plate 14:Miniature Painting of Prophet Jacob being suffers, Hadîkat üs-Süedâ, Konya Mawlānā Museum, 937, 1585 AD., Baghdad, Turkish, 24 Verso, $114 \times 96 \mathrm{~mm}$

S: Bagci Serpil, Konya Mevlana Muzesi, Resimli Elyazmalari, Istanbul, 2003, Pl.p.119. 


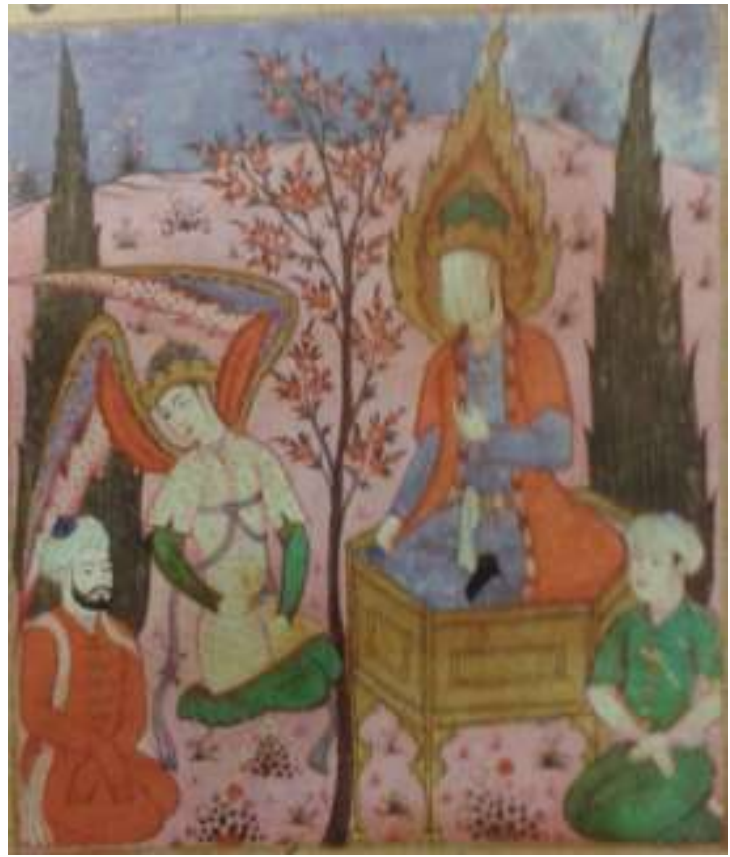

Plate 15: The Angel of Death eyes a man at Solomon's court, manuscript of the wonders of creations and the oddities of existence of Qazwini, Iran, Paintings of Late seventeenth century, Princeton University Library, Mss Garrett 82, 34.5×23.5 $\mathrm{cm}$

S: Berlekamp (P.), Wonder, Image, and Cosmos in Medieval Islam, London, 2011, P1.90.

Plate 16: Miniature Painting shows the martyrdom of Prophet Zakariya, Hadîkat üs-Süedâ, Konya Mawlānā Museum / P.N.101,

1585AD, Baghdad, Turkish, 49 Recto, Sizes: 160×104 mm.

S: Bagci Serpil, Konya Mevlana Muzesi, Resimli Elyazmalari, Istanbul, 2003, Pl.p.121

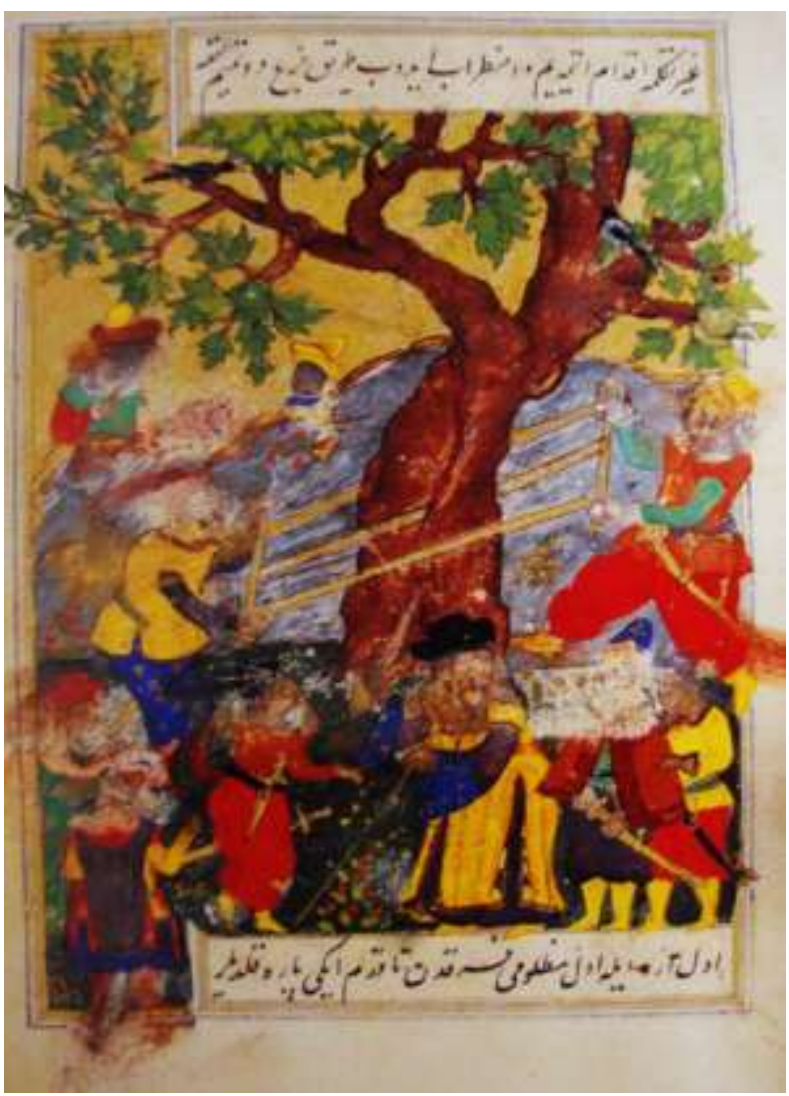



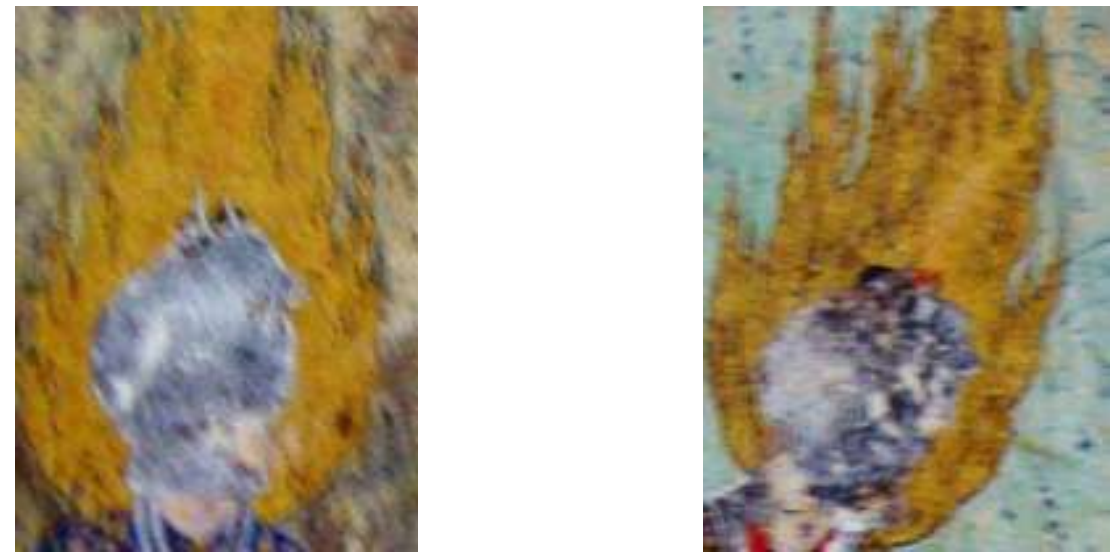

Type 1: Partially from cover head - extracted from plates $1 \& 3$
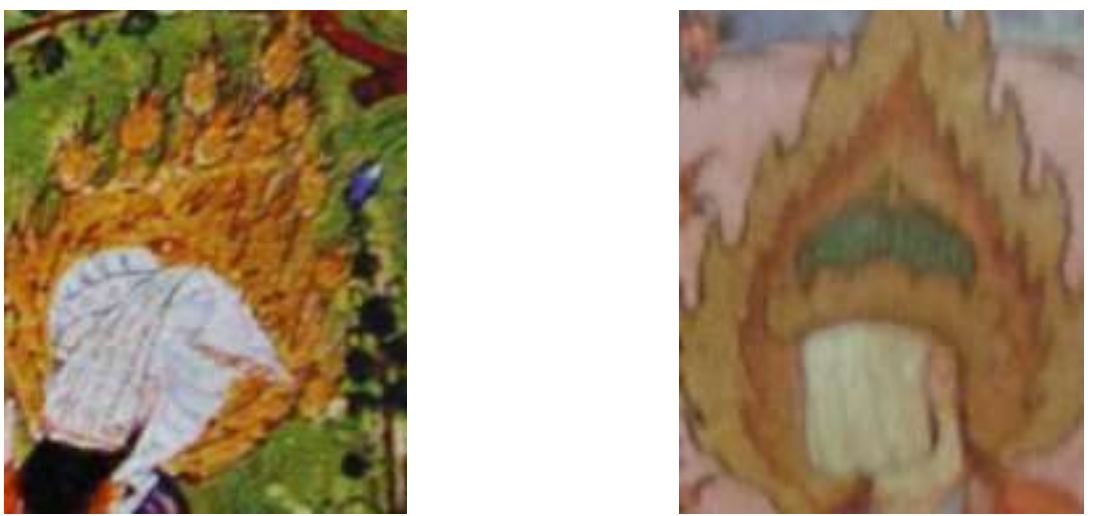

Type 2: Outer form of cover head- extracted from plates $7 \& 15$ 


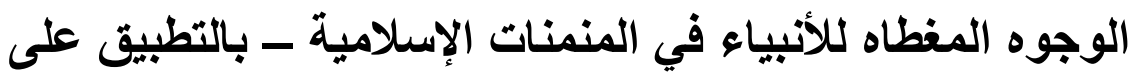

المخطوطات المصورة في القرن السادي عشر بمتحف مولانا بكونية

\section{د.إبراهيم محمد إبراهيم العسال هولهودئ.}

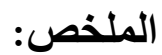

لقد إهتم المصور المُسلم بتصوير الثخصيات الدينية وقام بالتعبير عن قدسيتها بملمحين

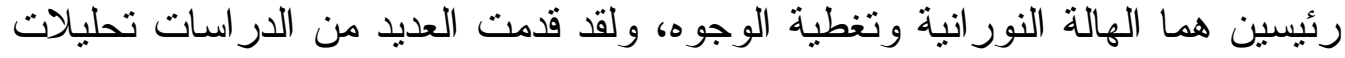

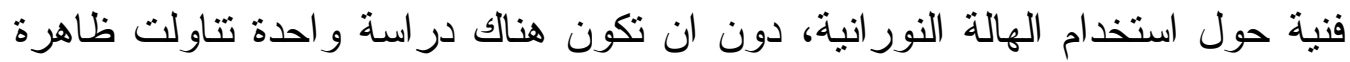

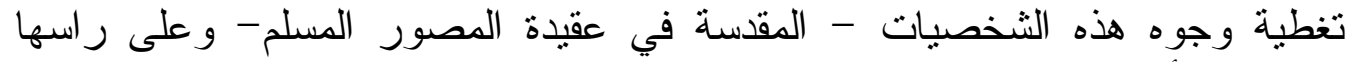
تصاوير الأنبياء. هذه آن

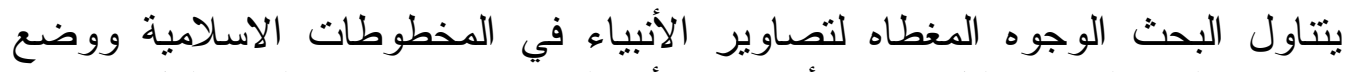

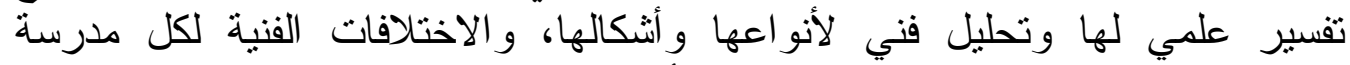

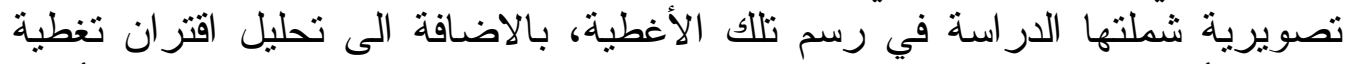

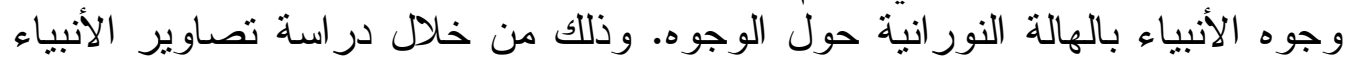

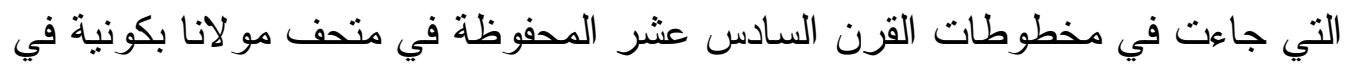

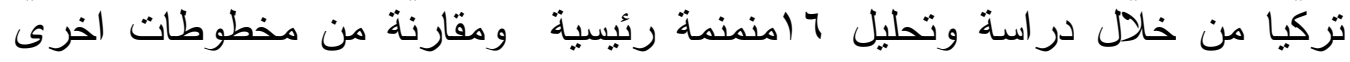

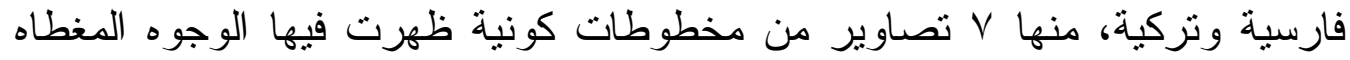

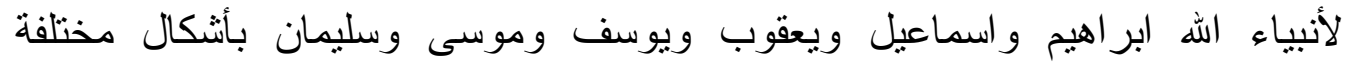

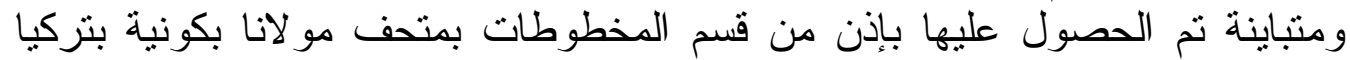

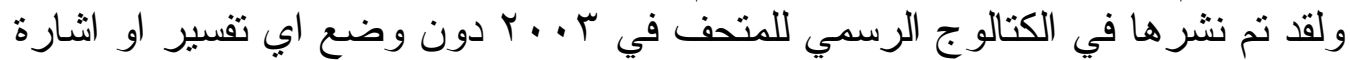

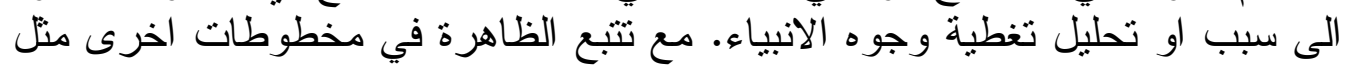

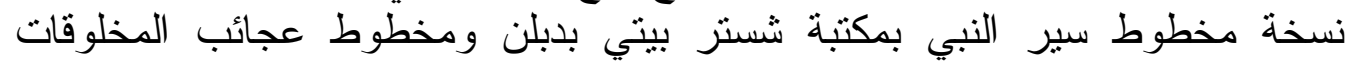

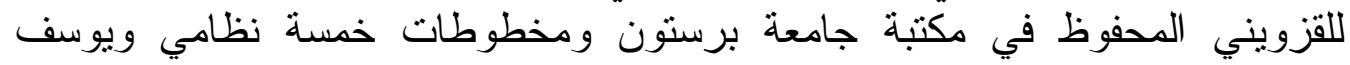

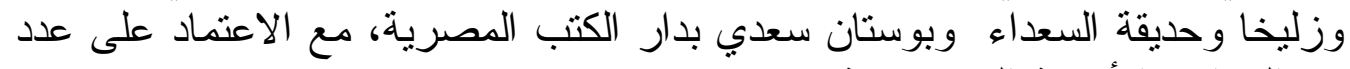
من المر اجع الأجنبية المتخصصة.

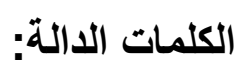

المنمنمات الاسلامية - تصاوير الأنبياء - التصوير الديني - متحف مو لانا في كونية الإنية - مخطوطات القرن السادس عشر - التصوير الإسلادي الأيني

•مدرس الاثار الاسلامية بقسم الارشاد السياحي بمعه سيناء العالي للسياحة ibrahimelassal2@gmail.com 